\title{
Trends in Illegal Killing of African Elephants (Loxodonta africana) in the Luangwa and Zambezi Ecosystems of Zambia
}

\author{
Vincent R. Nyirenda ${ }^{1}$, Peter A. Lindsey ${ }^{2}$, Edward Phiri ${ }^{3}$, Ian Stevenson ${ }^{4}$, Chansa Chomba ${ }^{5}$, Ngawo Namukonde ${ }^{1}$, \\ Willem J. Myburgh ${ }^{6} \&$ Brian K. Reilly $^{6}$ \\ ${ }^{1}$ Department of Zoology and Aquatic Services, School of Natural Resources, Copperbelt University, Kitwe, Zambia \\ ${ }^{2}$ Department of Zoology and Entomology, Mammal Research Institute, University of Pretoria, Pretoria, South Africa \\ ${ }^{3}$ Lusaka Agreement Task Force, Nairobi, Kenya; Directorate of Conservation and Management, Zambia \\ Wildlife Authority, Chilanga, Zambia \\ ${ }^{4}$ Conservation Lower Zambezi, Chirundu, Zambia \\ ${ }^{5}$ Disaster Management Training Centre, School of Agriculture and Natural Resources, Mulungushi University, \\ Kabwe, Zambia \\ ${ }^{6}$ Department of Nature Conservation, Faculty of Science, Tshwane University of Technology, Pretoria, South Africa \\ Correspondence: Vincent R. Nyirenda, Department of Zoology and Aquatic Sciences, School of Natural \\ Resources, Copperbelt University, Kitwe, Zambia, Tel: 260-977-352-035. Email: nyirendavr@hotmail.com
}

Received: December 21, 2014 Accepted: January 8, 2015 Online Published: March 6, 2015

doi:10.5539/enrr.v5n2p24 URL: http://dx.doi.org/10.5539/enrr.v5n2p24

\begin{abstract}
The resurgence in African elephant (Loxodonta africana) poaching for ivory and bushmeat threatens the persistence of elephant populations, continent wide. In addressing the scourge, monitoring of illegal killings of elephants plays a key role in effectively directing counter measures. This study evaluated spatiotemporal trends and patterns in elephant poaching. Illegal killing of elephants occurred mostly along major rivers, mainly in late dry season during which period elephants were more vulnerable to illegal exploitation. However, during the wet season, retaliatory killings of "problem elephants" marauding crop fields also took place. Elephant poaching was attributed to socio-economic and ecological drivers such as high poverty levels, weak governance, high demand for elephant ivory, and low social capital. These drivers are likely to apply to other elephant range states as well. We propose that local strategies that empower communities economically, build broad-based law enforcement capacity in stakeholders to counter illegal killing of elephants, and which positively shift the risk/reward ratio for ivory poachers trade, be urgently developed and implemented.
\end{abstract}

Key words: CITES, elephant poaching , ivory trade, resource monitoring

\section{Introduction}

The risk of local extinction of African elephants (Loxodontaafricana) in the 37 range states is a growing concern. Illegal wildlife trade is driving global extirpation of populations of commercially valuable species (Wittemyer, Northrup, Blanc, Douglas-Hamilton, \& Omondi, 2014). African elephants are illegally killed for ivory and bushmeat in increasingly unsustainable numbers (Bennett et al., 2007; Lindsey et al., 2013; Maiselset al., 2013; Nellemann, Formo, Blanc, Skinner, Milliken, \& De Meulenaer, 2013; Wittemyer, Daballen, \& Douglas-Hamilton, 2013). Though wildlife poaching results in modest returns for entire communities, such illegal activity is often attractive to individuals because of the high associated private returns and limited benefits from legal wildlife based land uses (Lindsey et al., 2011; Lindsey et al., 2013; Rentsch \& Damon, 2013). Furthermore, elephants often impose significant costs to communities via damage to crops (Lamarque et al., 2009). Lastly, commercial poaching is often conducted by individuals who are from areas distant from the wildlife areas, whose motives are unaffected by local benefits to communities derived from wildlife. This suite of issues creates challenges to reduce illegal killing of elephants.

There has been a major resurgence in the illegal elephant killing in the last few years, resulting in the decline and even local extinction of some elephant populations (Douglas-Hamilton, 2009; Poulsen, Clark, Mavah, \& Elkan, 2009; CITES et al., 2013; Wittemeyer et al., 2014). Subsequently, range states and international non-governmental organisations (NGOs) held the first African Elephant Summit in Gaborone, Botswana from 2-4 December 2013 to 
agree on urgent measures to counteract this resurgence. These measures combine market and non-market based strategies to address demand and supply of elephant parts and derivatives (IUCN, 2013). Non-market based approaches deal with issues such as governance and collaborative action in law enforcement.

In the Luangwa Valley, Zambia, African elephant populations experienced excessive illegal exploitation in the 1970's and 80's, primarily for ivory and later for both ivory and bushmeat (Leader-Williams, Albon, \& Berry, 1990; Jachmann \& Billiouw, 1997; Dalal-Clayton \& Child, 2003) (Table 3). Lower Zambezi ecosystem also experienced excessive elephant poaching during the late 1970s and early1980s, and the illegal harvest of elephants has continued until present (Table 4). Despite the ban by the Convention on International Trade in Endangered Species of Wild Fauna and Flora (CITES) in 1989 (Lausanne, CoP7) on international trade in elephants, their parts and derivatives, illegal killing of elephants continues unabated.

Monitoring of the Illegal Killing of Elephants (MIKE) programme was established in 60 selected sites of the elephant range in Africa and Asia by CITES (Bangkok, Conf. 10.10, Rev. CoP16). One of the 31 MIKE sites in Africa is South Luangwa National Park in Zambia. The MIKE programme provides information for making management and enforcement decisions, improving ability to monitor elephant populations, detecting changes in levels of illegal killing, and assessing the effectiveness of law enforcement. Information collection centres on elephant population sizes and trends, incidence and trends in illegal killing, and measures of the effort employed for the detection and prevention of illegal killing. The methods applied in MIKE sites for monitoring illegally killed elephants have also been replicated for non-MIKE sites such as Lower Zambezi ecosystem. In addition to MIKE programme related monitoring, assessing and identifying underlying local drivers of elephant poaching remain critical (Jachmann, 2012). This study attempts to achieve site-based understanding on elephant poaching to provide bases from which to make management decisions.

\section{Methods and Materials}

\subsection{Study Sites}

The study was conducted across three sites in Zambia: a) Lower Zambezi National Park (NP) $\left(4,092 \mathrm{~km}^{2}\right)$ and Chiawa Game Management Area (GMA) $\left(2,344 \mathrm{~km}^{2}\right)$ (hereafter collectively referred to as the 'Lower Zambezi', Figure 1); b) North Luangwa NP $\left(4,636 \mathrm{~km}^{2}\right)$, Mukungule GMA $\left(6,500 \mathrm{~km}^{2}\right)$, Musalangu GMA $\left(17,350 \mathrm{~km}^{2}\right)$ and Munyamadzi GMA $\left(3,300 \mathrm{~km}^{2}\right)$ (hereafter referred to as 'North Luangwa') (Figure 2); c) South Luangwa NP $\left(9,050 \mathrm{~km}^{2}\right)$ and Lupande GMA $\left(4,840 \mathrm{~km}^{2}\right)$ (which together comprise the MIKE site) (hereafter referred to as 'South Luangwa' - Figure 3). More than $72 \%$ of Zambia's elephant population occur in the Luangwa Valley, being elephant stronghold (McIntyre, 2004; Chomba, Simukonda, Nyirenda, \& Chisangano, 2012). Unlike in the GMAs, human habitation is excluded from national parks except for park management purposes (CSO, 2012). Inhabitants of the GMAs are mainly subsistence farmers, though some derive income from largely illegal bushmeat hunting.

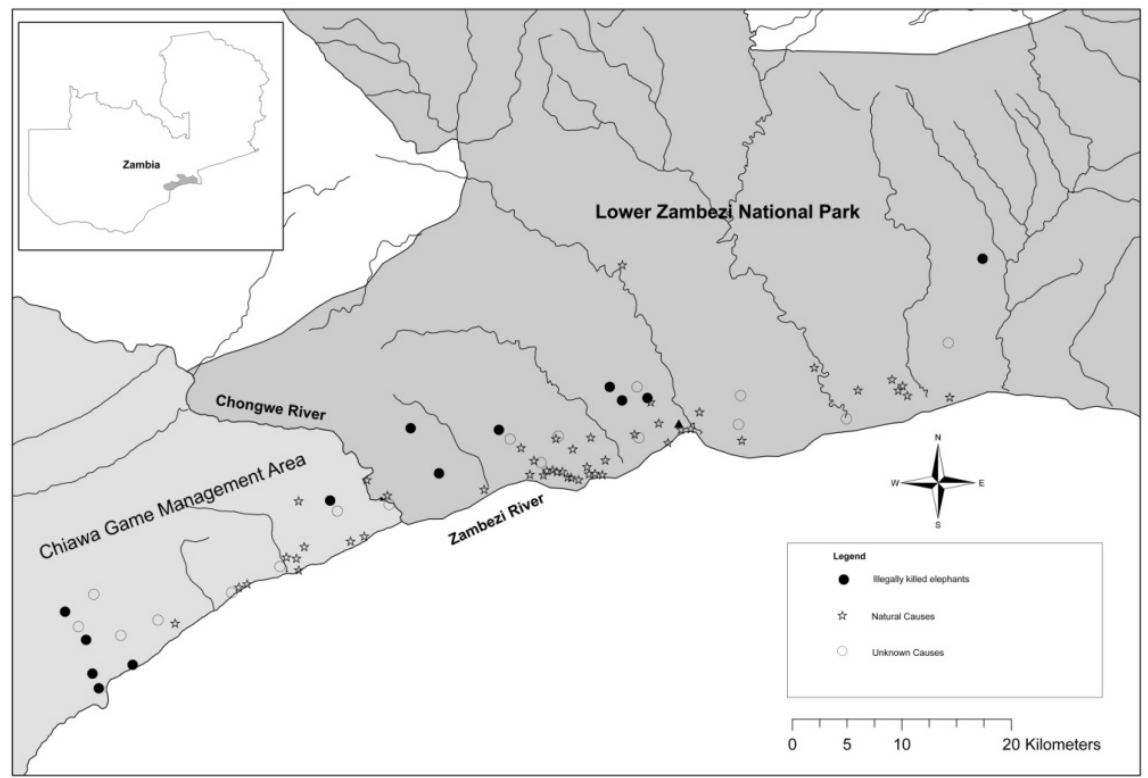

Figure 1. Geographical locations of illegal killings of elephants encountered in the Lower Zambezi ecosystem, Zambia, 2012-2013 


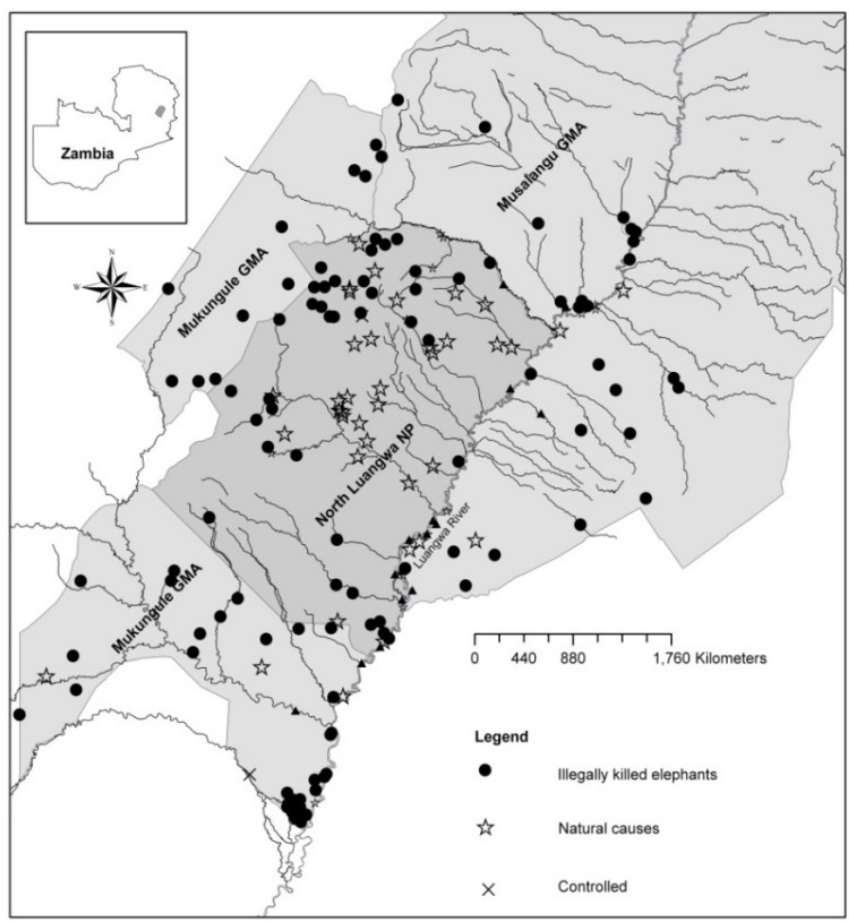

Figure 2. Geographical locations of illegal killings of elephants encountered in the North Luangwa ecosystem, Zambia, 2007-2013

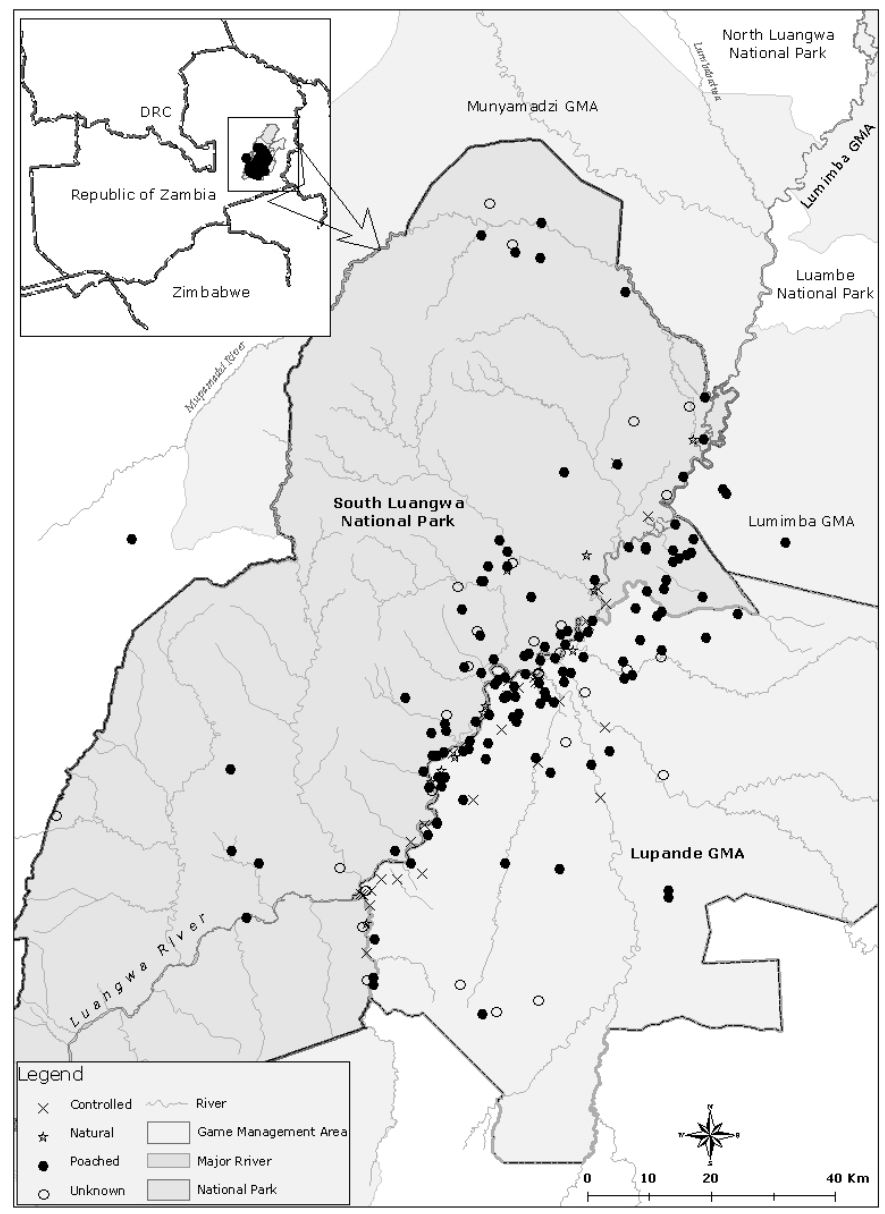

Figure 3. Geographical locations of illegal killings of elephants encountered in the South Luangwa MIKE site, eastern Zambia, 2010-2013 


\subsection{Assessing Elephant Mortalities}

Trained patrol teams collected elephant mortality data during January 2012 to December 2013 in the Lower Zambezi, January 2007 to December 2013 in North Luangwa, and January 2010 to December 2013 in the South Luangwa MIKE site. There were 6-8 members in each patrol team. Occasionally, the patrol teams were assisted by use of aircraft in the detection of elephant mortalities. During surveillance flights, any sightings of elephant mortalities were georeferenced, recorded and communicated to patrol teams for physical inspection. Patrol teams searched the sites for evidence of elephant poaching. We assumed that mortality incidences and the detection rates of carcasses were unaffected by the cause of death. For each carcass, the geographical location, age of the elephant, sex, cause of death, and whether poachers had removed ivory and meat, were recorded. Data from legal elephant sports hunting, which occurs on a small scale CITES voluntary quota of 60 individuals per annum, were not included. There were four age classes for allotment of individual carcass: fresh ( $\leq 1$ month), recent $(>1$ month and $\leq 1$ year), old ( $>1$ year) or very old ( $\leq 10$ years), following Douglas-Hamilton and Hillman (1981).

The age and sex determination of elephant carcasses were conducted following Moss (1996). Sex was determined by tusk shape and weight (where tusks were available), head shape and genitalia. The cause of death was evaluated following Roffe, Friend, and Locke (1996) and was classified as: Poached by poisoning; Poached by snaring; Poached by shooting; Natural mortality; Management problem animal control; Accident or Unknown. Sex or cause of death were not denoted for elephant carcasses in the Old and Very Old carcass classes as it was impossible to identify. 'Intact'; 'Removed'; 'Naturally absent'; or 'Recovered' formed status of elephant ivory. 'Found'; 'Recovered'; 'Removed'; or 'Parts removed' constituted the elephant meat status. The season in which the carcass was found was recorded as: 'Late wet season' (January-March); 'Early dry season' (April-June); 'Late dry season' (July-September); and 'Early wet season' (October-December). Proportion of Illegally Killed Elephants (PIKE), defined as the total number of illegally killed elephants found divided by the total number of carcasses found per year (CITES et al., 2013; Nellemann et al., 2013), depicted severity of elephant poaching. Mean PIKE values were calculated within a $95 \%$ confidence interval.

We determined the impact of mortalities on the elephant population of the Luangwa Valley, Zambia, where the mortalities due to poaching were relatively high (Figure 4). Aerial survey reports (Tables 3, 4 and 5) gave data on elephant populations. D-tests (Norton-Griffiths, 1978) were used to test the significance of population changes between episodes of comparable population estimates. Calculations of carcass ratios provided further insights into the impact of elephant mortalities on populations. Carcass Ratio=(Number of dead elephants)/(Number of dead elephants+Number of live elephants)*100 (Douglas-Hamilton \& Burrill, 1991).

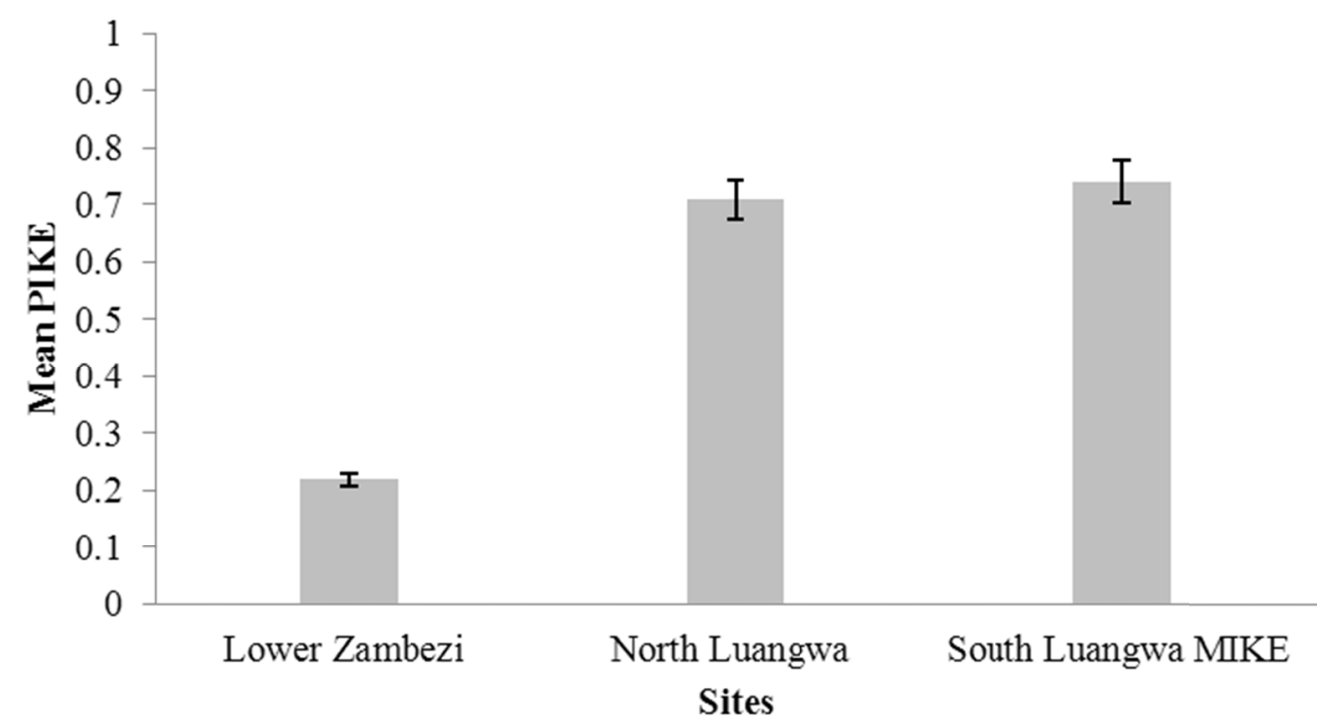

Figure 4. Trends in proportional illegal elephant mortalities encountered in Luangwa and Lower Zambezi ecosystems of Zambia, between 2007-2013 


\section{Results}

\subsection{Spatiotemporal Distribution of Elephant Mortalities}

At Lower Zambezi, there were 87 elephant mortalities during 2012-2013. Most mortalities occurred within riparian zones of Zambezi River and its tributaries (Figure 1). The PIKE value declined from $32.1 \%(n=9)$ in 2012 to $17.0 \%(\mathrm{n}=10)$ in 2013 , and averaged $21.8 \%$ (Figure 4). Management control operations accounted for $1.1 \%$ $(\mathrm{n}=1)$, natural causes of death contributed more than half of mortalities at $55.2 \%(\mathrm{n}=48)$ and unknown causes comprised $21.8 \%(\mathrm{n}=19)$ of total mortalities. These mortalities were detected largely in late dry season and early wet season (Figure 5).

During 2007-2013, North Luangwa experienced 202 elephant mortalities. Many elephant mortalities occurred along the river systems, particularly during the dry season. However, there were also substantial mortalities away from rivers (Figure 2). This finding contrasted with the situations in South Luangwa and Lower Zambezi. In North Luangwa, the PIKE value increased from $50.0 \%$ in 2007 to $76.9 \%$ in 2013 and averaged $70.9 \%$ (Figure 4). Illegally killed elephants totalled $70.3 \%(\mathrm{n}=142)$ of the total mortalities. Management control operations accounted for $0.99 \%(n=2)$ and natural causes of death contributed $28.7 \%(n=58)$ of mortalities. Elephant poaching was detected most commonly in the late dry season (Figure 5).

There were 215 mortalities recorded in South Luangwa during 2010-2013. Most elephant poaching occurred close to the Luangwa River and its tributaries (Figure 3). The PIKE value was $58.5 \%$ in 2010, increased to $81.3 \%$ in 2013, and averaged $74.1 \%$ (Figure 4). Illegally killed elephants comprised $64.7 \%(\mathrm{n}=139)$ of total mortalities. Other mortality causes included: management control operations $(15.3 \% ; n=33)$; natural deaths $(5.6 \% ; n=12)$; and unknown causes $(14.4 \% ; n=31)$. Most elephant poaching was detected in late dry season (Figure 5).

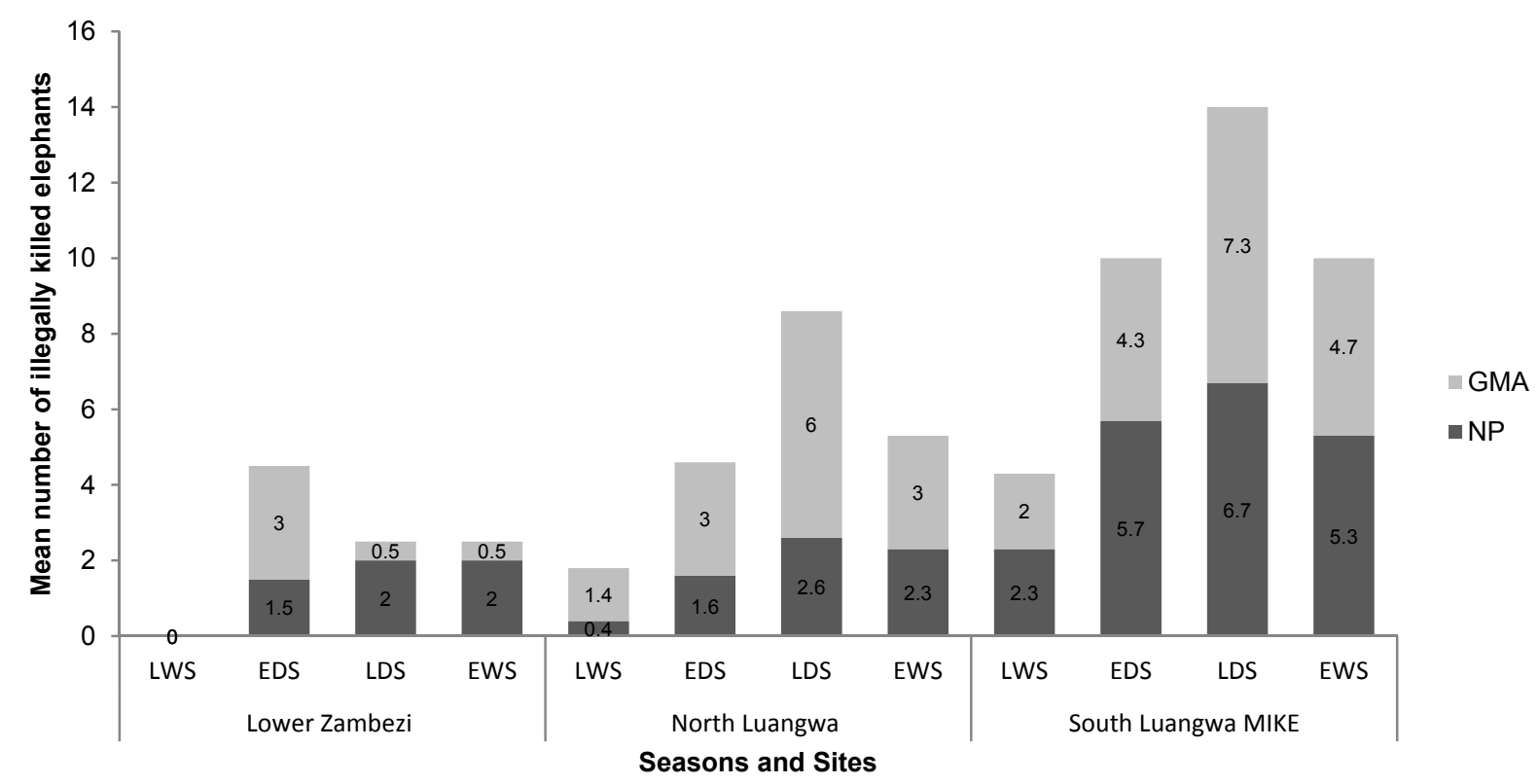

Figure 5. Mean number of illegally killed elephants in Luangwa and Zambezi ecosystems of Zambia, 2007-2013

\subsection{Elephant Age and Carcass Status}

Adult males were the most impacted upon age-sex category (Table 1). Poached elephants were typically adults or sub-adult, though young elephants were also snared or shot by local farmers and poachers in some cases. 
Table 1. Elephant carcass status and age by gender in Lower Zambezi and South Luangwa ecosystems, Zambia, 2010-2013

\begin{tabular}{lllllllll}
\hline & \multicolumn{3}{l}{ Lower Zambezi, 2012-2013 } & \multicolumn{5}{l}{ South Luangwa MIKE, 2010-2013 } \\
\cline { 2 - 8 } Carcass Status-Age & Male & Female & Unknown & Total & Male & Female & Unknown & Total \\
\hline Fresh-Adult & $18(5)$ & $8(2)$ & $5(3)$ & $31(10)$ & $106(73)$ & $19(15)$ & 0 & $125(88)$ \\
Fresh-Sub adult & $7(1)$ & 4 & 5 & $16(1)$ & $21(16)$ & $7(7)$ & 0 & $28(23)$ \\
Fresh-Young & 4 & & 6 & 10 & $3(3)$ & $3(2)$ & 0 & $6(5)$ \\
Fresh-Unknown & 0 & 0 & 0 & 0 & 0 & 0 & 0 & 0 \\
Recent-Adult & $6(2)$ & $(2)$ & 1 & $7(4)$ & $21(18)$ & $4(3)$ & 0 & $25(21)$ \\
Recent-Sub adult & 1 & 5 & 2 & 8 & $2(2)$ & 0 & 0 & $2(2)$ \\
Recent-Young & 0 & 0 & $4(1)$ & $4(1)$ & 0 & 0 & 0 & 0 \\
Recent-Unknown & 1 & $2(2)$ & $2(1)$ & $5(3)$ & 0 & 0 & 0 & 0 \\
Old-Adult & 3 & 0 & 0 & 3 & 0 & 0 & 20 & 20 \\
Old-Sub adult & 0 & 0 & 0 & 0 & 0 & 0 & 4 & 4 \\
Old-Young & 1 & 0 & 0 & 1 & 0 & 0 & 1 & 1 \\
Old-Unknown & 0 & 0 & 3 & 3 & 0 & 0 & 0 & 0 \\
Very Old-Adult & 0 & 0 & 0 & 0 & 0 & 0 & 2 & 2 \\
Very Old-Sub adult & 0 & 0 & 0 & 0 & 0 & 0 & 2 & 2 \\
Unknown & 0 & 0 & 0 & 0 & 0 & 0 & 0 & 0 \\
\hline Total & $\mathbf{4 1 ( 8 )}$ & $\mathbf{1 9 ( 6 )}$ & $\mathbf{2 8 ( 5 )}$ & $\mathbf{8 8 ( 1 9 )}$ & $\mathbf{1 5 3 ( 1 1 2 )}$ & $\mathbf{3 3 ( 2 7 )}$ & $\mathbf{2 9}$ & $\mathbf{2 1 5 ( 1 3 9 )}$ \\
\hline
\end{tabular}

N.B: In brackets in Table 1 are the numbers of elephants illegally poached and without brackets are total elephant mortalities.

\subsection{Illegal Meat and Ivory Extractions}

The motivation for elephant poaching was the acquisition of meat and ivory in all the three monitoring sites (Table 2). In North Luangwa however, elephants were killed primarily for ivory (Table 2). In some cases, illegally killed elephants had their tails cut off (e.g. 15.8\% in North Luangwa, and 42.1\% in Lower Zambezi). In other cases, neither meat nor ivory was removed from elephant carcasses, yet the elephants had evidence of having been either snared or shot. In the Lower Zambezi, however, elephants suspected to have died from anthrax, a disease caused by a bacterium called Bacillus anthracis had meat also intact. In 2013, some meat was found intact in North Luangwa, where three poached elephants and over 300 vultures of different species were associated with poisoning. The wildlife was poisoned by toxic carbamate pesticides called Carbofuran, traded as Furidan. In 2010, Aldicarb traded as Temik poison was used by poachers to kill an unknown number of elephants. The culprit was arrested by the wildlife authority and confessed to using Temik in elephant poaching.

Table 2. Percentage of meat and ivory extracted and a total number of illegally killed elephants in Luangwa Valley, eastern Zambia, 2007-2013

\begin{tabular}{|c|c|c|c|c|c|c|c|c|c|c|c|c|c|c|c|c|}
\hline \multirow[b]{3}{*}{ Parameter } & \multicolumn{3}{|c|}{ Lower Zambezi, 2012-2013 } & \multicolumn{8}{|c|}{ North Luangwa, 2007-2013 } & \multicolumn{5}{|c|}{ South Luangwa MIKE site, 2010-2013 } \\
\hline & \multicolumn{2}{|c|}{ Year } & \multirow{2}{*}{$\begin{array}{l}\text { Total No. } \\
\text { Killed }\end{array}$} & \multicolumn{7}{|c|}{ Year } & \multirow{2}{*}{$\begin{array}{c}\text { Total No. } \\
\text { Killed }\end{array}$} & \multicolumn{4}{|c|}{ Year } & \multirow{2}{*}{$\begin{array}{c}\text { Total No. } \\
\text { Killed }\end{array}$} \\
\hline & 2012 & 2013 & & 2007 & 2008 & 2009 & 2010 & 2011 & 2012 & 2013 & & 2010 & 2011 & 2012 & 2013 & \\
\hline Meat and ivory poached & 50.00 & 0 & 5 & 75.00 & 33.33 & 16.67 & 33.33 & 31.58 & 18.18 & 9.30 & 27 & 54.17 & 60.98 & 0 & 29.27 & 50 \\
\hline Meat and ivory intact & 0 & 33.33 & 3 & 0 & 0 & 0 & 16.67 & 5.26 & 0 & 11.63 & 8 & 8.33 & 14.63 & 37.50 & 12.20 & 25 \\
\hline Meat intact but ivory poached & 40.00 & 22.22 & 6 & 25.00 & 66.67 & 58.33 & 33.33 & 36.84 & 81.82 & 58.14 & 75 & 20.83 & 12.20 & 3.13 & 29.27 & 23 \\
\hline Meat poached but ivory intact & 10.00 & 44.44 & 5 & 0 & 0 & 16.67 & 16.67 & 15.79 & 0 & 18.60 & 15 & 12.50 & 2.44 & 59.38 & 29.27 & 35 \\
\hline $\begin{array}{l}\text { Meat poached but ivory } \\
\text { absent (tusklessness) }\end{array}$ & 0 & 0 & $\mathbf{0}$ & 0 & 0 & 8.33 & 0 & 10.53 & 0 & 2.33 & 4 & 4.17 & 4.88 & 0 & 0 & 3 \\
\hline $\begin{array}{l}\text { Meat intact but ivory } \\
\text { naturally absent } \\
\text { (tusklessness) }\end{array}$ & 0 & 0 & $\mathbf{0}$ & 0 & 0 & 0 & 0 & 0 & 0 & 0 & $\mathbf{0}$ & 0 & 4.88 & 0 & 0 & 3 \\
\hline Total $\%$ & 100.00 & 100.00 & - & 100.00 & 100.00 & 100.00 & 100.00 & 100.00 & 100.00 & 100.00 & - & 100.00 & 100.00 & 100.00 & 100.00 & - \\
\hline $\begin{array}{c}\text { Total number of illegally } \\
\text { killed elephants }\end{array}$ & 10 & 9 & 19 & 4 & 6 & 12 & 12 & 19 & 33 & 43 & 129 & 24 & 41 & 33 & 41 & 139 \\
\hline
\end{tabular}




\subsection{Impacts of Mortalities on Elephants Populations}

Elephant populations declined remarkably in the Luangwa Valley ecosystem during 2009-2012, primarily due to high levels of poaching (Frederick, 2013). A number of elephant carcasses is believed to have been underestimated in the Luangwa Valley during that period, hence, low carcass ratios recorded (Table 3). The detection levels were low compared to data sets generated by field patrol teams in Lower Zambezi and Luangwa ecosystems (Table 4 and 5). Field patrol data also incorporated data handed over from aerial surveillances for physical mortality verification. In addition, the large differences in aerial population estimates are due to variations in methods, resulting in high variances and wide confidence limits. There is varied carcass ratios sequel to high variances such that they became incomparable.

Table 3. Trends of Luangwa Valley System elephant populations and the carcasses detected from aerial surveys, 2009-2012

\begin{tabular}{ccccc}
\hline Year & Pop. Est. & Carcass & CR & $\boldsymbol{d}$-test (comparison with 2012) \\
\hline 2009 & 12,352 & 49 & 0.40 & -3.97 \\
2011 & 10,649 & 35 & 0.33 & -3.05 \\
2012 & 6,361 & 104 & 1.61 & - \\
\hline
\end{tabular}

Adapted from the Fredrick (2012) unpublished report data

Table 4. Comparison of African elephants in the Lower Zambezi National Park (old and fresh not separated)

\begin{tabular}{lllll}
\hline Year & Elephant Pop. Est. & Carcasses & Carcass Ratio & Sources \\
\hline 1970 & 564 & - & & Zyambo \& Simwanza, 2003 \\
1991 & 374 & 60 & 13.82 & Zyambo \& Simwanza, 2004 \\
1994 & 26 & 13 & 33.33 & Zyambo \& Simwanza, 2005 \\
1995 & 112 & 66 & 37.08 & Zyambo \& Simwanza, 2006 \\
1996 & 116 & 6 & 4.92 & Zyambo \& Simwanza, 2007 \\
2003 & 1303 & 14 & 1.06 & Simwanza, 2003 \\
2005 & 1710 & 7 & 0.41 & Simwanza, 2005 \\
2008 & 289 & 65 & 18.36 & Simukonda, 2008 \\
2013 & 2200 & 15 & 0.68 & Viljoen, 2013 \\
\hline
\end{tabular}

Table 5. Comparison of African elephants in the North Luangwa National Park (Only fresh carcasses included)

\begin{tabular}{lllll}
\hline Year & NLNP & Carcasses & Carcass Ratios & Sources \\
\hline 1973 & 17700 & - & - & Caughley \& Goddard, 1975 \\
1979 & 7360 & - & - & Douglas-Hamilton et al., 1979 \\
1985 & 5282 & - & - & Lewis, 1985 \\
1989 & 5077 & - & - & Owens, 1993 \\
1989 & 3170 & - & - & Owens, 1993 \\
1992 & 1650 & 3 & 0.18 & Owens, 1993 \\
1993 & 2282 & 5 & 0.22 & Owens, 1993 \\
1994 & 2000 & 5 & 0.25 & Owens et al., 1994 \\
1998 & 767 & 0 & 0.00 & Aucamp, 1998 \\
1999 & 1167 & 2 & 0.17 & Aucamp, 1999 \\
2000 & 1599 & 0 & 0.00 & Aucamp, 2000 \\
2001 & 3750 & - & - & Aucamp, 2001 \\
2003 & 3235 & 8 & 0.25 & Aucamp, 2003 \\
2009 & 3749 & 0 & 0.00 & WCS, 2010 \\
\hline
\end{tabular}




\subsection{Illegal Activities Correlates With Elephant Mortalities}

The Pearson correlation test for the five serious offences associated with the elephant poaching indicated that there was insignificant correlation between illegal killings of elephants and gunshot heard, footprint pairs, drying racks, poachers' camps or snares encountered during the foot surveillance patrols in the Lower Zambezi ecosystem. Gunshots heard, footprint pairs, drying racks, poachers camps and snares encountered were insignificantly correlated with poached elephants (Pearson correlation $=0.002, \mathrm{p}<0.995 ;-0.248, \mathrm{p}<0.413 ;-0.216, \mathrm{p}<0.479 ; 0.004$, $\mathrm{p}<0.990 ; 0.105, \mathrm{p}<0.732$ respectively). There were 93 gunshots heard on foot patrol per annum (median), with a range of $31-198$ gunshots during the period between 2001 and 2013. Footprint pairs encountered on patrols ranged from $4-58$ footprint pairs per annum, with a median of 17 footprint pairs. The drying racks encountered ranged from $0-38$, with a median of 5 drying racks per annum while poachers camps encountered were between $0-49$, with median of 4 poachers camps per annum. Encounters of snares ranged from $0-122$, with a median of 15 snare encounters per annum. Figure 6 summaries the annual correlates between 2001 and 2013.

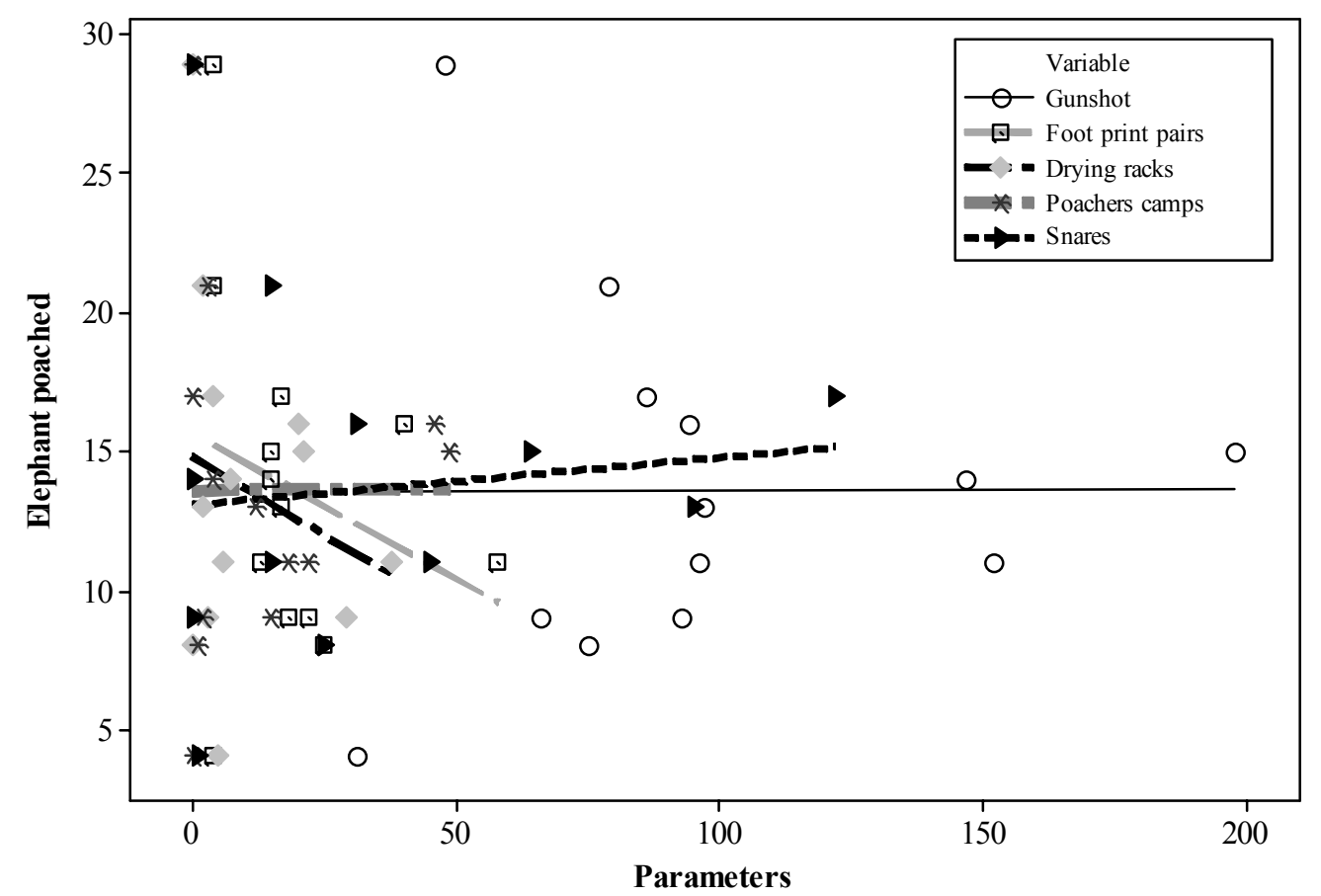

Figure 6. Annual correlates between poached elephants and five serious offences in the Lower Zambezi ecosystem, Zambia, 2001-2013

\section{Discussion}

The data from the three sites provided insights into elephant poaching. The ground-based method of monitoring illegally killed elephants; though labour intensive and covering a vast elephant range, proved useful as it provided key insights into trends in the elephant poaching. The underlying motives for the illegal killing of elephants appear to have been primarily ivory trafficking, the bushmeat trade and retaliatory killings.

Simukonda(2008) assessed that elephant populations in Luangwa Valley were either stable or increasing, based on $1.57 \%$ elephant carcass ratio for the Luangwa ecosystem. However, more recently, Frederick (2013) raised concerns over the increase in illegal killings of elephants in the Luangwa Valley. Based on 2012 population estimates by Frederick (2013) combined with the MIKE data, we derive 5.17\% elephant-carcass ratio in South Luangwa MIKE area. This maybe unsustainable as it exceeds the natural elephant population growth rate of 5\% (Dunham, 2012; CITES et al., 2013). Based on the 2012 aerial survey results of the Lower Zambezi (Viljoen, 2013), the calculated elephant carcass ration is $2.68 \%$. Our study re-emphasises elephant poaching threats as there is a growing trend of poaching (Figure 4 and Table1). For instance, high numbers of fresh and recent carcasses in Table 1 offer evidence of increasing threat of poaching to the Luangwa Valley elephant populations. PIKEs of greater than $0.5-0.54$ or $50-54 \%$ are precursors of severe poaching threats to elephant populations, resulting in declining populations (Nellemann et al., 2013; Wittemyer et al., 2014). Despite low ranger (scout) 
density of approximately 1 scout to $208 \mathrm{~km}^{2}$ (1:208) in Lower Zambezi in comparison to 1:50 and 1:36 in North and South Luangwa respectively, the PIKE for Lower Zambezi exceptionally remained lower than 54\% (Figure 4).

Though there were comparatively fewer illegally killed elephants annually in the three sites evaluated than some sites in Africa, they were higher than the average recorded in Southern Africa (CITES et al., 2013; Nellemann et al., 2013). Most elephant poaching occurred along the river systems in late dry seasons, as earlier stated. Elephant distribution was dependent on the water availability in dry and semi-dry areas (Chamaillé-Jammes, Valeix, \& Fritz, 2007; de Beer \& van Aarde, 2008). In dry season, elephants concentrate along the riparian environments in the Luangwa Valley (Simukonda, 2008; Chomba et al., 2012) and during the same season, local farmers rest from their main activity of subsistence agriculture and engage more in other economic activities, including in some cases illegal hunting of wildlife (Gibson \& Marks, 1995; Lewis, 2007). During the late dry season, mangoes (Mangifera indica) are ripe and elephants tend to devour the mangoes in the villages but also forage in vegetable gardens. Mangoes are common in villages in the Luangwa and Lower Zambezi, and invading elephants pose a threat to human life, and usually trigger retaliatory killings of elephants by inhabitants. However, a greater threat of poaching from other parts of the Luangwa Valley, also tend to confine elephants to the Luangwa Valley floor even during wet season, resulting in 'compression effect' (Lewis, 1986). In the Zambezi ecosystem, seasonal elephant movements between the escarpment and the valley floor have been well documented and are attributed to inter-seasonal pasture pressures (ZAWA, 2001).

Presumably due to their relatively larger body and ivory sizes (Moss, 1996), adult and sub-adult male elephants are targeted by poachers more than female elephants. Further, the status of tusklessness of a proportion of elephant population in the Luangwa Valley may have positive impact on containing levels of poaching of female elephants for ivory (Jachmann, Berry, \& Imae, 1995). During the wet season, local people either snare or shoot problem elephants that enter their fields and damage crops. Elephants that are not killed instantly retreat and eventually die in secluded places along the Luangwa River and its tributaries. Relatively high levels of poached elephants found with both meat and ivory intact (Table 2) are attributed to retaliatory killings and, in some cases, to intervening action from law enforcement officers. Further, the motives for collection of tails are unclear but probably for traditional rituals, and this threat requires forensic investigations. The recent practice of use of poison in elephant poaching also needs to be decisively addressed.

Despite being relatively well managed (Mwima, 2007), the study sites have a number of socio-economic and ecological drivers for elephant poaching that need to be addressed. These are characterized as: (1) high poverty levels among the rural populace, (2) inadequate legal benefits from wildlife utilisation, (3) weak governance, low social capital and prevalent corruption, (4) high demand for elephant ivory locally and abroad, and (5) inadequate natural resource monitoring and law enforcement.

With high human population growth of over 3.8\% (regional mean: 2.6\%) per annum in Lupande GMA (CSO, 2012), lack of protein and low rate of employment, elephant poaching is accentuated. Some key features exacerbating illegal killing of elephants in the Luangwa Valley include retaliatory killings of elephants by local farmers for crop raiding by marauding elephants (Nyirenda, Chansa, Myburgh, \& Reilly, 2011) and high incidences (60\%) of droughts (Gilvear, Winterbottom, \& Sichingabula, 2000), leading to food insecurity. Human influx in GMAs is common and poses a threat to wildlife persistence (Watson, Becker, McRobb, \&Kanyembo, 2013). Poverty levels in Zambia's rural areas, measured by UNDP Human Development Index remain high and typical of several other elephant range states (UNDP, 2011; World Bank, 2013). In such situations where black markets exist and non-poaching wages are low and poverty is prevalent, elephant poaching occurs. The benefits are greater than the costs and risks associated with poaching (Messer, 2010; Knapp, 2012). Proximity to urban markets increases demand for elephant products (Leader-Williams, Albon, \& Berry, 1990). Therefore, there is little incentive for skilled hunters to desist from poaching, which provides potentially high private benefits, for the sake of wildlife conservation. In this case, transformation of local hunters to conservationists insinuated by Gibson and Marks (1995) is put to test. The legal benefits acquired from wildlife are often inadequate to sufficiently provide incentives against illegal hunting of elephants (Dalal-Clayton \& Child, 2003).

Weak governance in traditional structures of local communities, low social capital and perceived and actual corruption (Nyirenda, Chansa, Myburgh, \& Reilly, 2010), undermine strategies to counter elephant poaching. Further, rampant human settlements and elephant habitat encroachments in GMAs of the Luangwa Valley facilitate elephant by-catch from wire snaring (Watson et al., 2013; Becker et al., 2013). Similarly, human encroachment in the form of human habitation, clearings, charcoal production and cultivation are widely spread in the Zambezi ecosystem (Viljoen, 2013). Local communities are also tempted to poach elephants through the increasing prices for elephant products, which are driven by increasing demand in consumer countries such as China (Nellemann et al., 2013). The rising price of the elephant and other poached products has also attracted 
organized crime to wildlife trading. Partly as a result of the high potential rewards, elephant poaching continues despite the harsh penalties associated with the illegal killing of the species and trading in elephant parts. Based on Zambia's wildlife legislation, illegal killing and trafficking of elephants attract penalties not less than 5 years and 7 years respectively and not exceeding a term of imprisonment of 20 years and 25 years respectively, without the option of a fine. Law enforcement efforts are undermined by funding shortages for protected area management (Lindsey et al. 2014), and by low salaries for law enforcement officers, which makes them vulnerable to being coerced into assisting ivory traders. Such factors may compromise the effectiveness of enforcement systems designed to save charismatic species (Bennett, 2011).

There is a need for improving and intensifying law enforcement efforts through implementation of rigorous systems to ensure that field officers are motivated trained, fittest, strongest people possible and to improve the working conditions of field officers. In the national parks, this would require elevated funding for Zambia Wildlife Authority (ZAWA) or co-management through partnerships between ZAWA, Non-Governmental Organisations and private sector. Wildlife populations in protected areas in Zambia with co-management agreements in place appear to be faring better than in parks without such support (Lindsey et al. 2014). There is currently co-management in place for North Luangwa and Lower Zambezi National Parks, and support is provided to ZAWA for law enforcement by an NGO in South Luangwa National Park. Other NGOs also involved provide support for law enforcement in some of the GMAs around those parks. Containing poaching of wildlife species requires financial and technical support towards local alternative and beneficial livelihoods in the adjacent GMAs.

In addition to elevated funding for law enforcement and stricter penalties for poaching and trafficking in elephant products, there is a need for other tools and regulations such as anti-money laundering and asset forfeiture legislation to be employed in support of wildlife legislation. There is a need to sustain the monitoring of illegal killings of elephants in protected areas and encourage use of resultant data by field staff to form the scientific bases for interventions. Efforts are required to tackle ivory and bushmeat traders in addition to the people who poach elephants. Collectively, such efforts would shift the risk/reward ratio for the would-be elephant poachers and make the illegal activity less attractive.

In addition to 'stick' approaches, there is a need for strategies that increase support for conservation. In the areas neighbouring the protected areas, there is a need for strategies to enable communities to benefit from tourism in the parks, and to own and benefit from wildlife that occurs in the GMAs (Lindsey et al., 2013). Such measures should ideally be combined with allocation of land ownership to local communities and land use planning, to limit on-going unplanned human immigration to areas adjacent to national parks. In the GMAs, there is a need for durable and equitable joint ventures between local communities and the private sector or NGOs which allow for emergence of elevated anti-poaching and wildlife management. Efforts to gather intelligence from local communities should be increased and are likely to be more effective if they receive a fairer share of the benefits from wildlife-based land uses in the area.

\section{Conclusion}

Resurgence of elephant poaching is a great concern at sites, national and international levels. The emerging patterns from monitoring of illegal killings of elephants on parameters such as spatiotemporal patterns, proportion of elephants illegally killed to other types of mortality and gender aspects of illegally killed elephants are critical for decision-making. Corresponding specific and multiple counteractive strategies are required to be put in place to urgently address the scourge at sites' levels along with those at national and international levels. Such strategies would target the supply chain of elephant products and key drivers for illegal killing of elephants (Keane, Jones, Edwards-Jones, \& Milner-Gulland, 2008; Challender \& MacMillan, 2014).

\section{Acknowledgements}

This study was conducted with the support of Zambia Wildlife Authority. We are grateful to all the field staff, too many to itemise, who took part in the data collection. The geographical map (Figure 3) was produced by Benson Kabungo.

\section{References}

Becker, M., McRobb, R., Watson, F., Droge, E., Kanyembo, B., Murdoch, J., \&Kakumbi, C. (2013). Evaluating wire-snare poaching trends and the impacts of by-catch on elephants and large carnivores. Biological Conservation, 158, 26-36.

Bennett, E. L. (2011). Another inconvenient truth: the failure of enforcement systems to save charismatic species. Oryx, 45(4), 476-479. 
Bennett, E. L., Blencowe, E., Brandon, K., Brown, D., Burn, R. W., Cowlishaw, G., ...Wilkie, D. S. (2007). Hunting for consensus: reconciling bushmeat harvest, conservation and development policy in West and Central Africa. Conservation Biology, 3, 884-887.

Central Statistical Office (CSO). (2012). Zambia 2010 Census of population and housing: population summary report. Lusaka: Central Statistical Office.

Challender, D. W. S., \& MacMillan, D. C. (2014). Poaching is more than an enforcement problem. Conservation Letter. http://dx.doi.org/10.1111/conl.12082

Chamaillé-Jammes, S., Valeix, M., \& Fritz, H. (2007). Managing heterogeneity in elephant distribution: interactions between elephant population density and surface-water availability. Journal of Applied Ecology, 44, 625-633.

Chomba, C., Simukonda, C., Nyirenda, V., \& Chisangano, F. (2012). Population status of the African elephant in Zambia. Journal of Ecology and the Natural Environment, 4(7), 186-193.

CITES, IUCN, SSC African Elephant Specialist Group, \& TRAFFIC International. (2013). Status of African elephant populations and levels of illegal killing and the illegal trade in ivory: a report to the African Elephant Summit.

Dalal-Clayton, B., \& Child, B. (2003). Lessons from Luangwa: the story of the Luangwa Integrated Resource Development Project, Zambia. Wildlife and Development Series 13. London: International Institute for Environment and Development.

de Beer, Y., \& van Aarde, R. J. (2008). Do landscape heterogeneity and water distribution explain aspects of elephant home range in southern Africa's arid savannah? Journal of Arid Environment, 72, 2017-2025.

Douglas-Hamilton, I. (2009). The current elephant poaching trend. Pachyderm, 45, 154-157.

Douglas-Hamilton, I., \& Burrill, A. (1991). Using elephant carcass ratios to determine population trends. African Wildlife Research and Management, 1, 98-105.

Douglas-Hamilton, I., \& Hillman, A. K. K. (1981). Elephant carcasses and skeletons as indicators of population trends.From low-level aerial survey techniques workshop. African Monograph No. 4, Addis Ababa.

Dunham,K. M. (2012). Trend in populations of elephant and other large herbivores in Gonarezhou National Park, Zimbabwe, as revealed by sample aerial surveys. African Journal of Ecology, 50(4), 476-488.

Frederick, H. (2013). Aerial survey report: Luangwa Valley, 2012. COMACO, Lusaka.

Gibson, C. C., \& Marks, S. A. (1995).Transforming rural hunters into conservationists: An assessment of community-based wildlife management programs in Africa. World Development, 23(6), 941-957.

Gilvear, D., Winterbottom, S., \& Sichingabula, H. (2000). Character of channel platform change and meander development: Luangwa River, Zambia. Earth Surface Processes and Landforms, 25(4), 421-436.

IUCN (The World Conservation Union). (2013). African Elephant Summit, Gaborone, Botswana, 2-4 December 2013: urgent measures. Retrieved December 4, 2013, from http://cms.iucn.org/downloads/africa_elephant_summit_final_urgent_measures_3_dec_2013.pdf

Jachmann, H. (2012). Pilot study to validate PIKE-based inferences at site level. Pachyderm, 52, 72-87.

Jachmann, H., \& Billiouw, M. (1997). Elephant poaching and law enforcement in the central Luangwa Valley, Zambia. Journal of Applied Ecology, 33, 1241-1250.

Jachmann, H., Berry, P. S. M., \& Imae, H. (1995). Tusklessness in African elephants: a future trend. African Journal of Ecology, 33(3), 230-235.

Keane, A., Jones, J. P. G., Edwards-Jones, G., Milner-Gulland, E. J. (2008). The sleeping policeman: understanding issues of enforcement and compliance in conservation. Animal Conservation, 11(2), 75-82.

Knapp, E. J. (2012). Why poaching pays: a summary of risks and benefits illegal hunters face in western Serengeti, Tanzania. Tropical Conservation Science, 5(4), 434-445.

Lamarque, F., Anderson, J., Fergusson, R., Lagrange, M., Osei-Owusu, Y., \& Bakker, L. (2009). Human-wildlife conflict in Africa: causes, consequences and management strategies. Rome: FAO.

Leader-Williams, N., Albon, S. D., \& Berry, P. S. M. (1990). Illegal exploitation of black rhinoceros and elephant populations: pattern of decline, law enforcement and patrol effort in Luangwa Valley, Zambia. Journal of Applied Ecology, 27, 1055-1087. 
Lewis, D. M. (1986). Disturbance effects on elephant feeding: evidence for compression in Luangwa Valley, Zambia. African Journal of Ecology, 24, 227-241.

Lewis, D. M. (2007).Opportunities and constraints for protected area management through increased connectivity to local livelihood needs in surrounding border areas: lessons from Luangwa Valley, Zambia. In: Redford K. H. and Fearn E, eds., Protected areas and human livelihoods. Working Paper No. 32. pp. 38-49. New York: Wildlife Conservation Society.

Lindsey, P. A., Nyirenda, V. R., Barnes, J. I., Becker, M. S., McRobb, R., Tambling, C.J., ... t'Sas-Rolfes, M. (2014) Underperformance of African protected area networks and the case for new conservation models: insights from Zambia. PLoS ONE, 9(5), e94109. http://dx.doi.org/10.1371/journal.pone.0094109

Lindsey, P., Balme, G., Becker, M., Begg, C., Bento, C., Bocchino, C., ...Zisadza, P. (2013). The bushmeat trade in African savannas: Impacts, drivers, and possible solutions. Biological Conservation, 160, 80-96.

Lindsey, P., Romañach, S., Matema, S., Matema, C., Mupamhadzi, I., \&Muvengwi, J. (2011).Dynamics and underlying causes of illegal bushmeat trade in Zimbabwe. Oryx, 45(1), 84-95.

Maisels, F., Strindberg, S., Blake, S., Wittemyer, G., Hart, J., Williamson, E. A., ... Warren, Y.(2013). Devastating decline of forest elephants in central Africa. PLoS ONE, 8(3), e59469. http://dx.doi.orrg/10.1371/journal.pone.0059469

McIntyre, C. (2004). Zambia: the Bradt travel guide. Third edition. St Peter: Chalfont, Bradt.

Messer, K. D. (2010). Protecting endangered species: when are shoot-on-sight policies the only viable option to stop poaching? Ecological Economics, 69, 2334-2340.

Moss, C. (1996). Getting to know a population. In: Kangwana K, ed., Studying elephants. Handbook series 7.Nairobi: African Wildlife Foundation.

Mwima, H. K. (2007). Management effectiveness tracking tool for protected areas. Lusaka: Ministry of Tourism, Environment and Natural Resources.

Nellemann, C., Formo, R. K., Blanc, J., Skinner, D., Milliken, T., \& De Meulenaer, T. (2013). Elephants in the dust: the African elephant crisis. A rapid response assessment. GRID, Arendal, Birkel and Trykkeri AS: United Nations Environment Programme. Retrieved March 4, 2014, from www.grida.no

Norton-Griffiths, M. (1978). Counting animals. Nairobi: African Wildlife Foundation.

Nyirenda, V. R., Chansa, W. C., Myburgh, W. J., \& Reilly, B. K. (2010). Social capital and community responses to natural resource management in the Luangwa Valley, Zambia. Journal of Sustainable Development in Africa, 12(8), 158-180.

Nyirenda, V. R., Chansa, W. C., Myburgh, W. J., \& Reilly, B. K. (2011).Wildlife crop depredation in the Luangwa Valley, Zambia. Journal of Ecology and the Natural Environment, 3(15), 481-491.

Poulsen, J. R., Clark, C. J., Mavah, G., \& Elkan, P. W. (2009). Bushmeat supply and consumption in a tropical logging concession in northern congo. Conservation Biology, 23, 1597-1608.

Rentsch, D., \& Damon, A. (2013). Prices, poaching, and protein alternatives: an analysis of bushmeat consumption around Serengeti National Park, Tanzania. Ecological Economics, 91, 1-9.

Roffe, T. J., Friend, M., \& Locke, L. N. (1996). Evaluation of causes of wildlife mortality. In: Bookhout TA., ed., Research and management techniques for wildlife and habitats(5th ed., revision, pp. 324-348). MA.: The Wildlife Society.

Simukonda, C. (2008). National-wide large mammal surveys and population estimates. Lusaka:New Horizon Printing Press.

United Nations Development Programme (UNDP). (2011). Zambia Human Development Report 2011: service delivery for sustainable human development. Lusaka: UNDP.

Viljoen, P. (2013). Lower Zambezi National Park, Rufunsa and Chiawa Game Management Areas: aerial wildlife survey. Chirundu: Conservation Lower Zambezi.

Watson, F., Becker, M. S., McRobb, R., \& Kanyembo, B. (2013). Spatial patterns of wire-snare poaching: implications for community conservation in buffer zones around National Parks. Biological Conservation, $168,1-9$. 
Wittemyer, G., Daballen, D., \& Douglas-Hamilton, I. (2013).Comparative demography of an at risk African elephant population. PLoS One, 8(1), e53726. http://dx.doi.org/10.1371/journal.pone.0053726

Wittemyer, G., Northrup, J. M., Blanc, J., Douglas-Hamilton, I., \& Omondi, P. (2014). Illegal killing for ivory drives global decline in African elephants. PNAS Early Edition, 1-5. http://dx.doi.org/10.1073/pnas.1403984111

World Bank.(2013). Country Partnership Strategy for the Republic of Zambia, year 2013-2016. Lusaka: World Bank.

Zambia Wildlife Authority (ZAWA).(2001). Lower Zambezi National Park, and Chiawa and Rufunsa Game Management AreasGeneral Management Plan. Chilanga: ZAWA.

\section{Copyrights}

Copyright for this article is retained by the author(s), with first publication rights granted to the journal.

This is an open-access article distributed under the terms and conditions of the Creative Commons Attribution license (http://creativecommons.org/licenses/by/3.0/). 